\title{
WOMEN CIVIL SERVANTS IN PUBLIC ADMINISTRATION IN BANGLADESH: DISCRIMINATED OR FAVOURED?
}

\author{
Mohammad Rezaul KARIM ${ }^{1}$ \\ DOI: $10.35782 /$ JCPP.2019.2.04
}

\begin{abstract}
This paper analyzes whether and to what extent women civil servants are discriminated in terms of recruitment and selection, appointment and placement, transfer, promotion and duty allocation in Administration in Bangladesh. This research applied a qualitative approach and an interview method was used for data collection. The research found that women faced differential treatments because of the nature of jobs and the lack of good working environment. Although there was no legal point for discrimination regarding HR practices, women were found fewer in number in some lucrative and challenging positions. The study revealed that they were not discriminated; they were rather favoured for their desired placements. They evaded some placements for the sake of household activities and childrens' wellbeing. The avoidance inhibited them to gain experiences that indirectly led to exclusion. The study recommends the clear career path, setting preconditions for promotion and arrangements of flexible working so that women can design their career and personal planning.
\end{abstract}

Keywords: woman civil servant, recruitment, placement, promotion, duty allocation, discrimination

\section{Introduction}

There has been a significant increase of womens' participation in employment in the public sector since 1980's, after the enactment of law with a provision of inclusion in the recruitment of civil service. There are 3068 positions of different ministries, departments, autonomous bodies occupied by women civil servants (WCSs) that comprises of 9.35 percent of total employment in the civil service of Bangladesh (Afroza, 2008). They are recruited through different cadre services including an administration cadre that belongs to the Ministry of Public Administration (MoPA). A

\footnotetext{
${ }^{1} \mathrm{PhD}$, Deputy Director Department of International Programme, Bangladesh Public Administration Training Centre. Savar, Dhaka-1343, Bangladesh. Email: rezapatc@gmail.com
} 
cadre is a specialized group of talented human resources with good opportunities for promotion, compensation package and other benefits both in cash and kinds. Bangladesh Civil Service (BCS) (Administration) is an important cadre among 28 cadre services. This cadre occupies the most powerful positions in decision-making and implementation. 5966 civil servants including 1228 women of administration cadre work in different positions in different ministries. Women constitute 20.58 percent of this cadre. Although womens' participation increased over three decades, their professional career is influenced by a myriad of factors such as policy provisions and practices, working conditions, organizational authority and power. Academics and researchers claim that women struggle through various seen and unseen obstacles and women are discriminated in terms of appointment, placement and promotion (Jahan, 2007; Jahan, 2010; Zafarullah, 2000). Civil servants suffer from a multitude of anomalies and deficiencies that include lack of human resource planning, inappropriate staffing policy, unplanned and unsystematic promotion process, unpredictable postings and transfers (Siddiquee, 2003). This paper is an attempt to analyze whether and to what extent women are discriminated in their professional career.

\section{Conceptual Framework}

The policy issues regarding the recruitment and selection, appointment and placement, promotion, and duty allocation are the major areas where women can be treated differently. Factors of these human resource practices influence the careers of women and create discrimination. Conceptual frameworks cover the following areas:

Recruitment and Selection: Bangladesh Public Service Commission (PSC) is responsible for recruiting civil servants through rigorous process. Recruitment and selection processes follow some steps for recruiting officials. MoPA sends a requisition to all ministries to send the number of officials is vacant which they need to fill in. With required number of officials intended by the ministries and other organization, MoPA sends it to the PSC for conducting examination for final selection. PSC conducts three stage-examination system for selecting the bright caliber students. First of all, PSC takes preliminary test for minimizing the number, then written examination of 1000 1100 marks on different 8 subjects of 800 marks and final step is the viva-voce of 200 marks (MoPA, 2018). This process takes about two years to complete. The recruitment ensures equality and diversity thus it is innate to have less emphasis on quality.

Appointment and Placement: After receiving the final list prepared by the PSC based on merit MoPA sends 27 other cadre officials (such as police, customs, taxation, foreign affairs, fisheries, agriculture etc.) to the concerned departments. Only members of BCS (Administration) cadre join the entry level post of managerial level job as Assistant Secretary in MoPA. They are placed at the field level. After the provision period (two years) of service and required training, they are placed either at the field level or in the ministry. Scope of placement widens after the service confirmation and promotion in the administrative hierarchy. Although some positions at the lower level like Assistant Chief, Chief Accounts Officer are filled by other cadres officials, most of posts of mid-level (Deputy Secretary) and above in the ministries are fulfilled by this group. 
Promotion: The first promotion takes place after five years of the first appointment and then continues to the ladder of hierarchy following certain conditions. Promotion can be either vertical or horizontal. Vertical promotion happens from lower rank to upper positions with higher pay scale and added benefits. Horizontal promotion keeps ranks \& pay scales unchanged and brings some extra fringe benefits. While considering the vertical promotion of officials, Annual Confidential Report (ACR) is considered because 85 percent marks in ACR for preceding some years is necessary. It is also compulsory to serve certain years of services to get the next promotion for example fives for Senior Assistant Secretary, five years for Deputy Secretary, three years for Joint Secretary, two years for Additional Secretary, one year for Secretary and to be included as one of the eight senior most Secretaries to be promoted as the Senior Secretary.

Discrimination: The term 'discrimination' refers to unequal treatment to the group having the same or similar qualification. Here discrimination means professionals are not posted in some positions although they have similar qualification, experience. The organizational issues tend to discriminate women professionals. Discrimination can be exercised in two ways: a) direct discrimination that means setting some conditions for one particular group and b) indirect discrimination is a means that organization does not show it in document but everyone is not treated equally for the same benefit. Indirect discrimination often happens due to the personal prejudice, social stigma, working environment and professional jealousy (Karim, 2013). Intentional and unintentional non-compliance of government rules and regulation inhibit employees to get the expected benefits.

\section{Research Methodology}

The research question was to analyze whether and to what extent women were discriminated in their professional career. It applied qualitative approach and was conducted on the civil servants of MoPA. Thirty-one civil servants including 17 women were interviewed. Through the interview and secondary data, the researcher tried to identify the areas where women were treated differently to discriminate them directly and indirectly. Their views on appointment, placement, promotion and job allocation were considered in this paper. Respondents were selected purposively and snowball technique was followed to select the respondents (Babbie, 2013). It has merit in this research that qualitative sampling is "very different from conventional sampling. It is based on informational, not statistical, considerations. Its purpose is to maximize information, not facilitate generalization." (Eliason, 2006:10). The snowball sampling covered all ranks i.e. Assistant Secretary, Senior Assistant Secretary, Deputy Secretary, Joint Secretary, Additional Secretary. Access to the respondents was gained through the gate-keeper i.e. Senior Secretary of MoPA. I also took the help of insider.

All interviews were conducted between August and October 2014 and lasted minimum 15 minutes to maximum one hour. Interview took place in MoPA. I noted down relevant points while I was conducting interviews. Interview was also recorded which later transcribed verbatim. Relevant quotes were written down and marked important 
matched with objectives. Data analysis was done thematically following the social constructivism approach (Creswell, 2013).

The age of Interviewees was between 28 and 58 years with an average of 49 years for male and 41 for female. Men were more experienced as they had average 22 years of service whereas women had an average of 14 years because men entered service before women. All respondents were highly educated having a Master degree. Respondents were managed through various techniques to find out organisational and policy issues that influence their professional career in creating discrimination.

\section{Results and Findings}

Data show that WCSs face differential treatments because of variation or deviation of practicing the laws, rules and regulations of employment policy and practices.

\section{Appointment of Women Civil Servants}

The enactment of law for inclusion of women in the civil service served as the legal ground for women. Any person meeting the qualification can apply and compete for the post. However, the 10 percent reserved seats for women served as positive discrimination for women to increase the number. It is proved that women joined the civil service by dint of their hard work and merit as it increased the number from two in 1982 to 1228 in 2018 (Afroza, 2008; Mahtab, 2007; MoPA, 2018). As women's inclusion in the civil service started in 1982 and more women in the lower level positions, they had gender pay gap (Table 1).

Table 1. Number of professionals and salary they received

\begin{tabular}{|c|c|c|}
\hline $\begin{array}{c}\text { Salary } \\
\text { Grade }\end{array}$ & $\begin{array}{c}\text { Salary Range in 2009 } \\
\text { (BDT*) }\end{array}$ & $\begin{array}{c}\text { Salary Range in 2015 } \\
\text { (BDT*) }\end{array}$ \\
\hline 1 & 40000 fixed & 78000 \\
\hline 2 & $33500-39500$ & $66000-76490$ \\
\hline 3 & $29000-35600$ & $56500-74400$ \\
\hline 4 & $25750-33750$ & $50000-71200$ \\
\hline 5 & $22250-31250$ & $43000-69850$ \\
\hline 6 & $18500-29700$ & $35500-67010$ \\
\hline 7 & $15000-26200$ & $29000-49670$ \\
\hline 9 & $11000-14430$ & $22000-53060$ \\
\hline
\end{tabular}
Source: Government of Bangladesh, 2015

Source: Government of Bangladesh, 2015

*BDT stands for the Bangladeshi currency Taka. 1 US-Dollar $=85$ Taka.

However, this pay gap did not exist within the ranks. There is no discrimination between men and women in same rank as their salary is fixed according to pay scale and positional ranks. 
Women civil servants in public administration in Bangladesh | 47

\section{Placement}

Table 2 indicates that 5966 professionals including 1228 women of different ranks work in the administration of Bangladesh.

Table 2: Male-female Ratio of officers at managerial level in MoPA (total, as on $14^{\text {th }}$ of September 2014 and $28^{\text {th }}$ of November 2018)

\begin{tabular}{|c|c|c|c|c|c|c|}
\hline Rank & $\begin{array}{c}\text { Male } \\
\mathbf{2 0 1 4}\end{array}$ & $\begin{array}{c}\text { Male } \\
\mathbf{2 0 1 8}\end{array}$ & $\begin{array}{c}\text { Female } \\
\mathbf{2 0 1 4}\end{array}$ & $\begin{array}{c}\text { Female } \\
\mathbf{2 0 1 8}\end{array}$ & $\begin{array}{c}\text { Total } \\
\mathbf{2 0 1 4}\end{array}$ & $\begin{array}{c}\text { Total } \\
\mathbf{2 0 1 8}\end{array}$ \\
\hline Secretary & 59 & 75 & 4 & 9 & 63 & 84 \\
\hline Additional Secretary & 248 & 519 & 27 & 76 & 275 & 595 \\
\hline Joint Secretary & 801 & 678 & 110 & 72 & 911 & 759 \\
\hline Deputy Secretary & 1131 & 1511 & 162 & 329 & 1293 & 1840 \\
\hline $\begin{array}{c}\text { Senior Assistant } \\
\text { Secretary }\end{array}$ & 1209 & 962 & 350 & 312 & 1559 & 1275 \\
\hline Assistant Secretary & 823 & 983 & 312 & 430 & 1135 & 1413 \\
\hline Grand total & $\mathbf{4 2 7 1}$ & $\mathbf{4 7 2 8}$ & $\mathbf{9 6 5}$ & $\mathbf{1 2 2 8}$ & $\mathbf{5 2 3 6}$ & $\mathbf{5 9 6 6}$ \\
\hline
\end{tabular}

Source: Public Administration Computer Centre (PACC)-2014 and 2018, MoPA, Dhaka.

Women can be posted in different places; firstly the MoPA, the mother ministry which is situated in Dhaka, secondly other ministries in Dhaka, thirdly subordinate offices of MoPA at the field level and fourthly other organisations. The first two categories of placement are of Dhaka based; third one is outside the ministry (mainly outside Dhaka) and fourth one can be either in or outside Dhaka. This placement greatly influences the professional's career and personal life as the benefits vary from one place to another. Lower ranked professionals can hardly work in first two categories which mean professionals can not stay in Dhaka even if they need for their family purpose. Dhaka is a factor as it is the capital and different facilities are concentrated here. A total of 112 professionals including 38 women work in different positions in MoPA in Dhaka in 2014 (Table 3). Although total number increased in four years time, women's placement did not increase.

Table 3: Male-Female ratio working in MoPA, Dhaka

\begin{tabular}{|c|c|c|c|c|c|c|c|c|}
\hline Rank & $\begin{array}{c}\text { Male } \\
\text { (2014) }\end{array}$ & $\begin{array}{c}\text { Male } \\
\text { (2018) }\end{array}$ & $\begin{array}{c}\text { Female } \\
\mathbf{( 2 0 1 4 )}\end{array}$ & $\begin{array}{c}\text { Female } \\
\mathbf{( 2 0 1 8 )}\end{array}$ & $\begin{array}{c}\text { Total } \\
\mathbf{( 2 0 1 4 )}\end{array}$ & $\begin{array}{c}\text { Total } \\
\mathbf{( 2 0 1 8 )}\end{array}$ & $\begin{array}{c}\text { Vacant } \\
\text { 2018 }\end{array}$ & $\begin{array}{c}\text { Vacant } \\
\text { Posts }\end{array}$ \\
\hline Secretary & 1 & 1 & 0 & 0 & 1 & 1 & & 0 \\
\hline $\begin{array}{c}\text { Additional } \\
\text { Secretary }\end{array}$ & 3 & 9 & 2 & 5 & 5 & 14 & 1 & 0 \\
\hline $\begin{array}{c}\text { Joint } \\
\text { Secretary }\end{array}$ & 17 & 22 & 4 & 3 & 21 & 25 & 1 & 1 \\
\hline $\begin{array}{c}\text { Deputy } \\
\text { Secretary and } \\
\text { equivalent } \\
\text { officers }\end{array}$ & 13 & 43 & 10 & 20 & 23 & 63 & 2 & 2 \\
\hline
\end{tabular}




\begin{tabular}{|c|c|c|c|c|c|c|c|c|}
\hline Rank & $\begin{array}{c}\text { Male } \\
\mathbf{( 2 0 1 4 )}\end{array}$ & $\begin{array}{c}\text { Male } \\
\mathbf{( 2 0 1 8 )}\end{array}$ & $\begin{array}{c}\text { Female } \\
\mathbf{( 2 0 1 4 )}\end{array}$ & $\begin{array}{c}\text { Female } \\
\mathbf{( 2 0 1 8 )}\end{array}$ & $\begin{array}{c}\text { Total } \\
\mathbf{( 2 0 1 4 )}\end{array}$ & $\begin{array}{c}\text { Total } \\
\mathbf{( 2 0 1 8 )}\end{array}$ & $\begin{array}{c}\text { Vacant } \\
\mathbf{2 0 1 8}\end{array}$ & $\begin{array}{c}\text { Vacant } \\
\text { Posts }\end{array}$ \\
\hline $\begin{array}{c}\text { Senior } \\
\text { Assistant } \\
\text { Secretary and } \\
\text { equivalent } \\
\text { officers }\end{array}$ & 21 & 9 & 16 & 6 & 37 & 14 & 1 & 5 \\
\hline $\begin{array}{c}\text { Assistant } \\
\text { Programmers } \\
\text { and }\end{array}$ & 18 & 12 & 7 & 3 & 25 & 15 & 1 & 6 \\
$\begin{array}{c}\text { equivalent to } \\
\text { AS }\end{array}$ & $\mathbf{7 4}$ & $\mathbf{9 6}$ & $\mathbf{3 8}$ & $\mathbf{3 7}$ & $\mathbf{1 1 2}$ & $\mathbf{1 3 2}$ & $\mathbf{6}$ & $\mathbf{1 4}$ \\
\hline Grand total & & & & & & & \\
\hline
\end{tabular}

Source: Public Administration Computer Centre, MoPA 2014 and 2018

Table 3 also indicates that 38\% of women work in Dhaka around Dhaka which is double comparing to the percentage $(20.58 \%)$ in total women's employment. One of the main reasons for being in Dhaka is specific office time for which women can easily go back home and perform household activities. Men also acknowledged this reason. Spouses of women work in Dhaka that also helps to manage posting in the ministry. A Joint Secretary (woman) mentioned:

"I am lucky and privileged in terms posting as my husband is also a civil servant. After my posting in one place, I used to request the authority to place my husband in my working place or near. That's why I did not face any family dislocation."

Although MoPA in Dhaka is the mother ministry and it has limited duty posts, professionals also prefer other organization because they can get extra financial benefit. If they work in training organizations (fourth category), they receive 30\% extra with their regular salary and $20 \%$ in other organization as deputation (temporary basis) allowance (GoB, 2005; GoB, 2009b). This facility brings balance between work and life as they can stay in the capital with their family members and get more money. Fourth category placement also includes autonomous, corporation, UN bodies, embassies which have more diversity of work. Diversity of work may bring balance between work and life because of financial and non-financial benefits.

Placement in the central area (either in MoPA or other ministries or departments in Dhaka) and organisations outside Dhaka influences work and life of professionals. Officials working at the central area particularly in the ministries enjoy civic facilities of Dhaka city whereas officials working at the field level face more challenges. Some civil servants serve long time at the field level. They are posted in the ministry after promotion as Deputy Secretary or Joint Secretary (JS) and they feel deprived. Because opportunities come through MoPA in Dhaka and the first group is favored. The ministry now-a-days allocates some foreign training programs for field level administration. A group of officials try to manage posting in the ministry or in other organizations to stay in Dhaka. Less number of posts (580 out of 3477) in Dhaka is found vacant whereas a significant number (945 out of 2585) of posts are vacant at the 
field that creates pressure on working officials (MoPA, 2018). Third group maintains extended hour that creates obstacles to spend time with family members for which this placement is usually avoided by women.

The question is who is favoured for posting particularly in lucrative positions like Secretary, Joint Secretary (APD), Divisional Commissioner, Deputy Commissioner (DC), and Additional Deputy Commissioner. These posts are considered as the main attractions of joining this service. Only 8 women hold the highest position of administration which ministries are not deemed as the powerful ministries.

A woman made the follwoing comment:

"[Usually] woman is not placed as the secretary, and you will find very negligible number of women as secretaries. You will not find any woman in the most powerful ministries like Ministry of Home, MoPA, Ministry of Foreign Affairs, Ministry of Education and Ministry of Defense. If they are promoted and posted, they are in some less powerful ministries".

Women are discriminated in terms of attractive postings. Only one woman was found holding the position of DC of Manikgonj District and other 63 DCs were male in 2014 where six female DCs in 2018 (PACC, 2014; PACC, 2018). However, women are not posted in big districts. Similarly, JS (APD) is deemed as powerful position as he makes appointment, placement and deputation of all officials including senior officials to him. Woman was never posted in this position.

Women were found that they avoided HR jobs, Accounting and Finance where they need some expertise and some positions where they need quick decisions. Women are thought weak in some areas. Although society given role of child caring and household activities and lack of women-friendly working environment served as the obstacles for women, they also lack of skills to carry out these jobs.

A woman mentioned that:

"T believe women cannot take much pressure for which they can't do better in personnel management, accounting. These jobs are avoided by them and assigned to male officials."

Placement of Project Directors (PDs) for various projects is another important issue for professionals. DS and above officials can be posted as PDs for the project period. A competent professional is supposed to be posted as the head of the project, which has a practical ground to show the performance. Project has extra facility like charge allowance, vehicle facility, internal and foreign tours etc. A woman is not generally placed as PD. Only two WPs were found whereas 100 PDs are men (Table-4). Two women are working as the PD of two projects namely 'Women Empowerment to build Digital Bangladesh through ICT' and 'Economic Empowerment of Women Entrepreneur Project', which are related to women. It is a praiseworthy decision that a woman can understand deeply to empower women that does not mean that they are not capable for other projects. 
Table 4: Project Directors of Various Project under different ministries

\begin{tabular}{|l|c|c|c|}
\hline \multicolumn{1}{|c|}{ Rank } & Male & Female & Total \\
\hline Deputy Secretary & 23 & 0 & 23 \\
\hline Joint Secretary & 71 & 2 & 73 \\
\hline Additional Secretary & 6 & 0 & 6 \\
\hline Total & 100 & 2 & 102 \\
\hline
\end{tabular}

Source: Public Administration Computer Centre, MoP A, Dhaka. Accessed to bttp://pmis.mopa.gov.bd/pmis/Forms/seclist.php on 31.12.2014

Table 5: PS to Secretaries, Ministers, Parliamentary committees

\begin{tabular}{|l|c|c|c|}
\hline Rank & Male & Female & Total \\
\hline Assistant Secretary & 2 & 0 & 2 \\
\hline Senior Assistant Secretary & 87 & 2 & 89 \\
\hline Deputy Secretary & 5 & 0 & 5 \\
\hline Joint Secretary & 0 & 1 & 1 \\
\hline Additional Secretary & 5 & 0 & 2 \\
\hline Total & 96 & 3 & 99 \\
\hline
\end{tabular}

Source: Public Administration Computer Centre, MOPA, Dhaka. Accessed to

http://pmis.MOPA.gov.bd/pmis/Forms/seclist.php on 31.12.2014

Similar picture is found for the post of Private Secretary (PS) to the President, the Prime Minister, Ministers, State Ministers, Deputy Ministers, Chief Whip of the Parliament, Opposition Leader and Secretaries. Generally men are appointed as PS. Only four women out of 99 officials are holding this position where one woman (JS) is working as PS to Prime Minister (Table-5). The main consideration is woman as the Prime Minister is woman. Other two women were working as PS to secretary in two ministries which were headed by women. PS also has some attractive benefits and can exercise power.

\section{Seniority and Promotion}

The merit list prepared by the PSC at the first entry is the main basis for promoting officials. Following it, a seniority list is prepared for promotion and is maintained every time, which becomes unchanged after new promotion. Stipulated years of experience are needed for next promotion. Promotion can be either vertical or horizontal. Vertical promotion happens from lower rank to upper positions with higher pay scale and added benefits. Horizontal promotion keeps ranks \& pay scales unchanged and brings some extra benefits. While considering the vertical promotion of officials, Annual Confidential Report (ACR) is considered because 85 percent marks in ACR for preceding five years is necessary. Haque (2012) identified some disadvantages of ACR such as likelihood of bossism, flattering tendency among ratees and highly susceptible to rater's (initiating or counter signing officer) biases for which it does not reflect the real performance of professionals. Women are fewer in upper positions which means they hold less power and authority and it is usually exercised by men (Table 1). 


\section{Duty Allocation}

Civil servants are assigned for job according to their ranks and are entitled to enjoy the benefits of assigned posts. However, some are not assigned any job. There are two distinct groups that one working group and other group members are called officer on special duty (OSD). Literally OSDs should be posted in some jobs where they need special support, expertise and they should be given special preference. In reality, the OSDs do not have work. They come to office and receive salary. Now the OSD is not term used as noun as identification rather it is used as the adjective to show the state of a person without job. It is derogative word in bureaucracy in Bangladesh. There are many reasons for making an employee OSD for example, study purpose, immediate after promotion, training, political reason, disciplinary. A person can be OSD for short and long term. Short term OSD is a regular process while long term OSD is deemed as punishment, if not for study or lien or training. The table- 8 is of long term OSDs where no woman was found. All OSDs receive salary from the MoPA in Dhaka. There is a significant number of OSDs for a long time for which government is not getting service spending a lot for them. There are 163 officials mostly men found OSDs in the last five years (Table-6). Government had to spend 501058000 BDT (USD 6387988.44) (One taka $=0.013$ Dollar, calculated on 25.03.2015) without getting any service from them. Long term OSDs are frustrated and deprived of service benefits. They have no power. However, women were found very few as OSD.

Table 6: Number of OSDs and their reasons 2014

\begin{tabular}{|l|c|c|c|c|c|}
\hline & Male & Female & Total & $\begin{array}{c}\text { OSD for } \\
\text { Study }\end{array}$ & $\begin{array}{c}\text { OSD for } \\
\text { other } \\
\text { reason }\end{array}$ \\
\hline $\begin{array}{l}\text { Assistant } \\
\text { Secretary }\end{array}$ & 44 & 12 & 56 & 24 & 32 \\
\hline $\begin{array}{l}\text { Senior } \\
\text { Assistant } \\
\text { Secretary }\end{array}$ & 105 & 27 & 132 & 93 & 109 \\
\hline $\begin{array}{l}\text { Deputy } \\
\text { Secretary }\end{array}$ & 67 & 9 & 76 & 15 & 61 \\
\hline $\begin{array}{l}\text { Joint } \\
\text { Secretary }\end{array}$ & 98 & 6 & 104 & 2 & 102 \\
\hline $\begin{array}{l}\text { Assistant } \\
\text { Secretary }\end{array}$ & 21 & 1 & 22 & 0 & 22 \\
\hline Secretary & 2 & 0 & 2 & 0 & 2 \\
\hline Total & 337 & 55 & 392 & 134 & 328 \\
\hline
\end{tabular}


Table 7: Expenditure for OSD (in Taka): 2009-2013

\begin{tabular}{|c|c|c|c|c|}
\hline Secretary & $\begin{array}{c}\text { Additional } \\
\text { Secretary }\end{array}$ & Joint Secretary & $\begin{array}{c}\text { Deputy } \\
\text { Secretary }\end{array}$ & Total \\
\hline 7810000 & 96614000 & 324184000 & 72450000 & 501058000 \\
\hline
\end{tabular}

Source: Kawser and Islam, 2014

Table 8: Professionals attached to different ministries

\begin{tabular}{|l|c|c|c|}
\hline Rank & Male & Female & Total \\
\hline Assistant Secretary & 14 & 9 & 23 \\
\hline Senior Assistant Secretary & 4 & 0 & 4 \\
\hline Deputy Secretary & 31 & 2 & 33 \\
\hline Joint Secretary & 108 & 18 & 126 \\
\hline Additional Secretary & 17 & 1 & 18 \\
\hline Secretary Total & 1 & 0 & 1 \\
\hline \multicolumn{1}{|c|}{ Tory } & $175(85 \%)$ & $30(15 \%)$ & 205 \\
\hline
\end{tabular}

Source: Public Administration Computer Centre, MoPA, Dhaka. Accessed at

bttp://pmis.MoPA.gov.bd/pmis/Forms/seclist.php on 31.12.2016

Table 9: Frequency of Transfer of Professionals

\begin{tabular}{|l|c|c|c|}
\hline \multicolumn{1}{|c|}{ Gender } & Level & Years of Service & No. of Transfer \\
\hline Female & AS & 3 & 5 \\
\hline & SAS & 9.25 & 6.5 \\
\hline & DS & 22.83 & 3 \\
\hline & JS & 25 & 10 \\
\hline & Addl. Sec. & 30 & 2 \\
\hline & Average (F) & 13.94 & 4.29 \\
\hline Male & AS & 0 & 0 \\
\hline & SAS & 11 & 5.67 \\
\hline & DS & 21 & 6.25 \\
\hline & JS & 26 & 14 \\
\hline & Addl. Sec. & 29 & 7.83 \\
\hline & Average (M) & 21.92 & 5.75 \\
\hline All (Male and Female) & Average & 17.55 & \\
\hline
\end{tabular}

The study found that MoPA promoted civil servants more than the vacant posts that created the problem of placement (Table 9). For this extra promotion, civil servants were found working in the lower desks or as attached officer in other ministries while they were receiving salary from MoPA. Women were less affected from this duty allocation as only 30 women were attached whereas 175 men faced this problem (Table 9).

\section{Discriminated or favoured?}

It is no doubt women's participation is less in employment although that is strengthened by the positive discrimination through legal provisions. Women are 
blamed that they came for quota. They proved their capacity in achieving the onefourth of total employment.

The appointment at the entry level is done by the PSC through open competitive examination where every candidate has equal chance for final selection. Less representation of women in the civil service requires the positive discrimination which is maintained through 10 percent reserve seats. Less representation is influenced by the late inclusion, the lower rate of higher education of women, traditional culture. Traditionally women are 'home centred' than 'work centred' (Hakim, 200). Usually they prefer household activities even, women were found that they emphasized household activities than office work and professional development. Their learning about the household works came from the experience of childhood where the saw these were traditionally performed by the female counterparts of the family. Women emphasized their family responsibilities as they avoided training programs, foreign degrees, challenging jobs. Emphasizing household and performing family activities by women were guided by social norms and tradition that also forced them to be 'home centered' (Zafarullah, 2000; Hakim, 2000). As they accentuate family more than career, they avoid or they are avoided to place in some positions, it ultimately creates discrimination. On the other hand, avoidance of some jobs and stayed in Dhaka is considered as preference for which men are discriminated. Three women were found who never worked outside Dhaka whereas no single was found for men. However, those who were single, married but lived alone were found 'work centered' where reasons contradict with the preference theory as it happened due to the situation not for individual choices (Hakim, 2000).

This study shows that men constitute the majority in MoPA. However, women are favoured compared to men, especially in some cases such as transfers and placements. This contradicts male preference theory, which assumes that when working culture is dominated by male as individual preference, those are favoured by male (Crompton, 2006; Hofstede and Hofstede, 2005; Zafarullah, 2000). The findings of the study, especially overrepresentation of women in MoPA contradicts this view. Women are privileged in terms of posting in MoPA or near Dhaka comparing with the field level. About 45 per cent posts are filled up by women among all who work in MoPA in Dhaka (Table-3). Studies show that, only 31\% of females work in ministries or other organizations in Dhaka and offices near Dhaka which is double about $(20.58 \%)$ and more than thrice $(9.35 \%)$ compared to the percentage of women employment in MoPA and in the civil service respectively (Table 1 ). Men prefer challenging jobs, more work, spending more time with official activities whereas women prefer their house and do as the minimal work as they need to maintain in the office (Hofstede \& Hofstede, 2005). That's why women prefer structured and stipulated time frame for work. It is one of the main attractions to be posted at the central level of MoPA or any ministry in the secretariat. It creates the difference in getting benefits. Professionals like to stay in or around the centralized power. It was evident that women were discriminated in terms of assigning some lucrative jobs which were favoured for men thinking that men are more capable of performing better (Crompton, 2006). Because of nature of works, women at the field level positions encounter more problems and challenges that create obstacles to balance between work and life (Jahan, 2010). 
There were no formal flexible working arrangements in MoPA for which informal flexibility emerged. Informal flexibility acted as stronger work-life balance strategy at the workplace because it was practiced at the time of personal need (Holt and Thaulow (1996:83-85). The informal flexibility is enjoyed through mutual understanding and mainly by women for family purpose. A woman told that she had to take this informal flexibility for her child. This finding contradicts partially to the research findings as the previous research showed that men had the trend to utilise the informal flexibility keeping the good relation where women did not use it and worked more than women (Zafarullah, 2000). Informal flexibility happens sometimes forcefully due to external pressures such as traffic jam, unavailability of public transport, political demonstration on the street and habitual nature of employees (Zafarullah, 2000). MoPA practiced extended working hour at the field level. The extended working hour becomes the necessity for the workload and professionals who are single and living alone, can utilise their time and can get benefit in return. Those who spend more time have the opportunity to achieve professional development and trust of seniors that may count in future. Extended working hour creates negative effect on professionals and children which office does not take care of.

The consequences outside works happened due to pressure of work intensify negative issues for which women avoid some placements (Guest, 2002). This research found that factors related to career such as superseding (which means promoting juniors to a person who has fulfilled all conditions to be promoted), non-promotion, placement in undesired places served as the negative factors and permeate to family and create conflict between work and life. These negative issues affected the individual performance, harmony in the administration. Opportunities sometime intensify the problem particularly for women when they need to rearrange family activities because of training programs or tours either in country or abroad. It creates conflict as the nonsupport may come from family members particularly from in-laws. It becomes very difficult to break the invisible but strong boundary and enjoy the benefits (Clark, 2000).

Women avoid placement in some positions, which are in challenging in nature, dislocate their family, maintain longer working hour. Although this avoidance restricts them gaining experience of some jobs which result in some lucrative placements, it comes as positive effect for them. Lucrative and challenging jobs require political connection which they can easily avoid as this affect negatively later for promotion or placement when the government changes. The research found that men were superseded and made OSDs more in number whereas women were less affected by this bad culture.

Women prefer to stay in or around Dhaka and avoid posting outside Dhaka considering their family dislocation. They are favoured for their choices which are not usually favoured for men. It was found that average rate of transfer of men was about 8 times comparing to 4 times for women (Appendix-J). Men suffered for frequent transfer as it increased the cost of living maintaining two families in two different places. 


\section{Conclusions and Recommendations}

Discrimination of women civil servants in MoPA in terms of appointment, placement, promotion, duty allocation depends on the nature of job and women's avoidance. This unintentional exclusion happens because of lack of women-friendly environment, structural indulgences, traditional role of household activities assigned for women. They also evade challenging jobs, which are mainly at the field level. Although this avoidance happens intentionally or unintentionally, it makes them less confident about the responsibilities. However, they are also benefitted from the placement and duty allocation because of fewer women in the civil service, lack of suitable facility for women. Lack of good working environment or adverse working environment not only creates obstacle to work in some positions but also serves as the positive factor because women can easily show this as the cause and get better placement in the capital or in other city areas according to their desire.

The scenario has changed than that of first recruitment. However, anomalies and discrepancies happen due to the lack of human resource planning, inappropriate staffing policy, erratic transfers and postings, unplanned and unsystematic promotion that may create discrimination for men and women (Siddiquee, 2003). MoPA can follow the steps stated below to reduce the discrimination:

- There should be compulsory service outside of Dhaka for a certain period time and earn points for each placement to be considered for next promotion. This can be in another way that everybody should start their job in the rural areas for three years and again after getting new promotion they will be posted in rural or hill districts. Benefits of serving in those less desirable areas will be added in ACR. If this rational system can be developed officials will plan their career and match with their family needs. Professional will know about the next posting well ahead at least one or two years ahead so that they can plan about their children. Transfer and placement can be made in line with the organizational needs and professionals' choices.

- Women-friendly working environment should be developed so that they don't avoid some placement. Work-life balance policies such as daycare center, flexible working time arrangements (FWTAs), and family leave can be introduced to attract for any placement. FWTAs may include annualized work, work from home through online, flexible time so that professionals utilize these options when they need for their family reasons. This can be a godsend to civil servants when they have young children or children with special need.

- Women professionals should also make plan for developing the career with the organizational policies so that they can attain training programmes, gain required professional experience. This plan needs to be matched with the personal planning of family formation, getting children and their well-being, getting households works done. WCSs should realize what they would emphasize to get benefits most without hampering either. They also can plan with their spouses if they are dual earners. This planning will ease the mental burden and reduce the work-life conflict. 
It is claimed by the academics and researchers that women at the workplace in the public sector are discriminated directly or indirectly in terms of human recourse practices such as recruitment, placement, transfer, providing congenial environment, delegation of power and duty allocation. There is no policy documents found that supports this statement rather they are favoured. Exclusion happens unintentionally because of external factors related to the social constraints, family issues and individual mechanism.

\section{Acknowledgments}

This is an excerpt of larger research of PhD Dissertation. The author is extremely grateful to the Adviser of the dissertation Professor Dr. Juree Vichit-Vadakan, the Chair of Center for Philanthropy and Civil Society, Thailand. The financial support of National Institute of Development Administration (NIDA) through its full funded scholarship is also gratefully acknowledged.

\section{References}

Afroza, S. (2008). The Emerging Role of Women in Civil Service (Administration) of Bangladesh: An Introspective Analysis (From 1971-2007). Doctoral Dissertation, University of Karachi.

Babbie, E. (2013). The Practice of Social Research. Australia: Wordsworth Cengage Learning.

Clark, S.C. (2000). Work/Family Border Theory: A New Theory of Work/Family Balance. Human Relations, 53(6), 747-770.

Creswell, J.W. (2013). Qualitative Inquiry and Research Design: Choosing among Five Approaches. Sage Publications.

Cromption, R. (2006) (ed.). Gender and Work. In Kathy Davis, Mary Evans and Judith Lorber, Handbook of Gender and Women's Studies. London: Sage Publications.

Ellions, S.L. (2006). Factors influencing job satisfaction among state conservation officers. Policing: An International Journal of Police Strategies \& Management, 29(1), 6-18

Government of Bangladesh (2015), Public Servants (Salary and Allowance) Order 2015, Dhaka: Bangladesh Government Press.

Guest, D.E. (2002). Perspectives on the study of work-life balance. Social Science Information, 41(2), 255-279.

Hakim, C. (2000). Work-Lifestyle Choices in the 21st Century: Preference Theory: Preference Theory. Oxford: Oxford University Press.

Haque, M.A. (2012). Performance Appraisal System of Bangladesh Civil Service: An Analysis of its Efficacy. International Public Management Review, 13(1), 38-60

Hofstede, G. \& Hofstede, G.J. (2005). Cultures and Organizations: Software of the Mind. New York: McGraw-Hill.

Holt, H. \& Thaulow, I. (1996), in S. Lewis and J. Lewis. (eds): The Work-Family Challenge: Retbinking Employment. London: SAGE Publications.

Jahan, M. (2007). Gender Mainstreaming In Bangladesh Civil Service: Prospects And Constraints. Asian Affairs, 29 1), 41-72.

Jahan, R. (2010). Problems of working at the field level: A study of women civil servants of Bangladesh. Master's Thesis (unpublished). Dhaka: University of North-South

Karim, M.R. (2013). Are ethnic minorities fairly treated in the labour market in the UK? International Journal of Development and Sustainability, 2(3), 1770-1786. 
Kawser, A. \& Islam, S. (2014). Imbalance in Administration due to Excessive Promotion, The Samakal, August 8 (Bengali Daily Newspaper).

Mahtab, N. (2007). Women in Bangladesh: From Inequality to Empowerment. Dhaka: A. H. Development Publishing House.

Ministry of Public Administration (MoPA), 2013, Annual Report of Ministry of Public Administration, 2012-2013 (in Bangla).

MoPA. 2014, Bangladesh Civil Service (Age, Qualification and Examination for Direct Recruitment) Rules, 2014 (in Bangla). Dhaka: Government Publication.

Public Administration Computer Centre (PACC), 2014, Ministry of Public Administration. Dhaka: Bangladesh Secretariat. Website: www.MOPA.gov.bd/pacc.

PACC, 2018, Ministry of Public Administration. Dhaka: Bangladesh Secretariat. Website: www.MOPA.gov.bd/pacc.

Patton, M.Q. (1987). How to Use Qualitative Methods in Evaluation. London, New York and New Delhi: Sage Publications.

Siddiquee, N.A. (2003). Human Resource Management in Bangladesh Civil Service: Constraints and Contradictions. International Journal of Public Administration, 26(1), 35-60.

Zafarullah, H. (2000). Through the brick wall, and the glass ceiling: Women in the civil service in Bangladesh. Gender, Work \& Organization, 7(3), 197-209. 